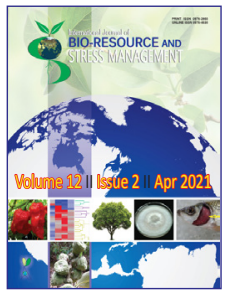

\title{
Astrologically Designed Medicinal Gardens of India
}

\author{
Maneesha S. R.", P. Vidula, V. A. Ubarhande and E. B. Chakurkar
}

ICAR-Central Coastal Agricultural Research Institute, Ela, Old Goa, Goa (403 402), India

\begin{abstract}
Open Access
Corresponding Author

Maneesha S. R.

e-mail: maneesha.sr@icar.gov.in

Citation: Maneesha et al., 2021. Astrologically Designed Medicinal Gardens of India. International Journal of Bio-resource and Stress Management 2021, 12(2), 108-120. HTTPS://DOI.ORG/10.23910/1.2021.2165.

Copyright: (c) 2021 Maneesha et al. This is an open access article that permits unrestricted use, distribution and reproduction in any medium after the author(s) and source are credited.

Data Availability Statement: Legal restrictions are imposed on the public sharing of raw data. However, authors have full right to transfer or share the data in raw form upon request subject to either meeting the conditions of the original consents and the original research study. Further, access of data needs to meet whether the user complies with the ethical and legal obligations as data controllers to allow for secondary use of the data outside of the original study.
\end{abstract}

Conflict of interests: The authors have declared that no conflict of interest exists.

Acknowledgement: The authors are deeply thankful to all the Co-PIs of the institute project 'Prospects and promotion of agro ecotourism in coastal regions of India'. We also thank, Dr.A.R. Desai, Head i/c (Hort. Sciences section) for his support, Mr. Viswajit Prajapathi, Technical officer (Computer) for designing the layout of the gardens, Mrs. Aviprit V. Ubarhande, Young Professional -II and Mr. Rupesh Devidas, Young Professional -I for their help in collection of plants, establishment and management of navgraha/ rashi/ nakshatra vatika at ICAR-CCARI, Goa.

Article History

RECEIVED on $02^{\text {nd }}$ November 2020 RECEIVED in revised form $29^{\text {th }}$ February 2021 ACCEPTED in final form $05^{\text {th }}$ April 2021

\begin{abstract}
Herbs and horoscopes have played important roles in ancient human life. Vedic astrology describes nine grahas (planets), 12 rashis (zodiacs) and 27 nakshatras (stars/ constellations). It was believed that every person should plant and take care of the tree, animal or bird assigned to his/ her rashi/ nakshatra to please the ruling deity. The concept says that the position of these bodies at the time of birth or their movement in the celestial globe has influence on humans. Our ancestors established navagraha/ rashi/ nakshatra vatika or van near sacred places with representative plants to worship and ensure good health. Most of these representative plants are rare medicinal tree species, which emphasize our ancestors' forevision to conserve these genetic resources ex situ to share its medicinal uses with the preceding generation. These tree species are rich in secondary metabolites such as antioxidants, alkaloids, saponins, flavanoids, terpenes, and tannins and are widely used in traditional treatment systems. It is proven that these plant species release more oxygen compared to other species and hence sitting near these trees generate positive energy. The phytochemistry and pharmacological significance of these species have been proven by scientific research by modern science. Therapeutic, industrial and cosmetic relevance of these trees are being exploited in various parts of the world. Conservation of these species in navagraha/ rashi/ nakshatra vatikas established in urban spaces can refresh the minds of city dwellers by ensuring greenery and enriching biodiversity.
\end{abstract}

Keywords: Vedic astrology, astral garden, celestial garden, zodiac garden

\section{Introduction}

Astrology is a traditional science that studies the influence of celestial objects on human life. It is believed that the position of stars and planets at the time of birth of a person can influence the life events. According to Vedic astrology, grahas (planets) are celestial bodies moving from west to east in a circular path. This circular path is divided in $30^{\circ}$ angle to form rashis (zodiacs) which are further divided in $13^{\circ} 20^{\prime}$ angle to form a nakshatra (constellation). A nakshatra is a mythical figure formed by a group of stars in the sky. There are nine grahas, 12 rashis and 27 nakshatras. Each of these grahas/ rashis/ nakshatras are assigned with a deity, tree, animal and bird. In ancient India, birth chart or horoscope of new borns were prepared to analyse and predict his/ her nature and future with good and bad dashas (period of influence). The ruling deity was worshiped and the tree, animal or bird assigned to his/ her rashi or nakshatra were taken care to diminish the bad influences and bring good fortune.

Plants had great significance in human life since time immemorial. Vedic 
scripts reveal the spiritual and cultural significance of plants in ancient India (Jain and Kapoor, 2007). A few plants posses' auspicious status and is a must in poojas and ceremonies, even now. Traditional treatment systems were also based on plants and plant based preparations. Ancient Indians treated diseases and disorders with the help of herbs and horoscope. The blend of medicine and astrology was very strong in those days. Most of the plants associated with navagrahas/rashis/ nakshatras are rare and medicinally important species found in wild. They are potent source of antioxidants. They release more oxygen compared to other species and that's how they refresh and provide positive vibe to a person standing near to it. Our ancestors planted them together in sacred places in astrological design to form 'vatikas' or 'vans' such as navagraha vatika (celestial garden), rashi vatika and nakshatra vatika (astral garden). They might have thought to protect these plants from extinction by conserving them ex situ by providing them a sacred halo (Figure 1). Ayurveda says that the diseases are caused by tridoshas (vata, pita and kapha) which has significant relation to grahas. Worshiping navagrahas or the representatives of them will help to reduce the ill effects of the diseases. Surya is considered as a graha and it is related to power and longevity. Chandra affects digestive system and mental health. Budha is related to respiratory and skin diseases. Shukra is related to reproductive organs and Mangal affects muscular strength. Guru impacts metabolism, liver and pancreas while Shani is associated with nerve-related issues. Rahu and Ketu are related to fears and phobias. The details of navagraha plants and their position in the navagraha vatika are given in Table 1.

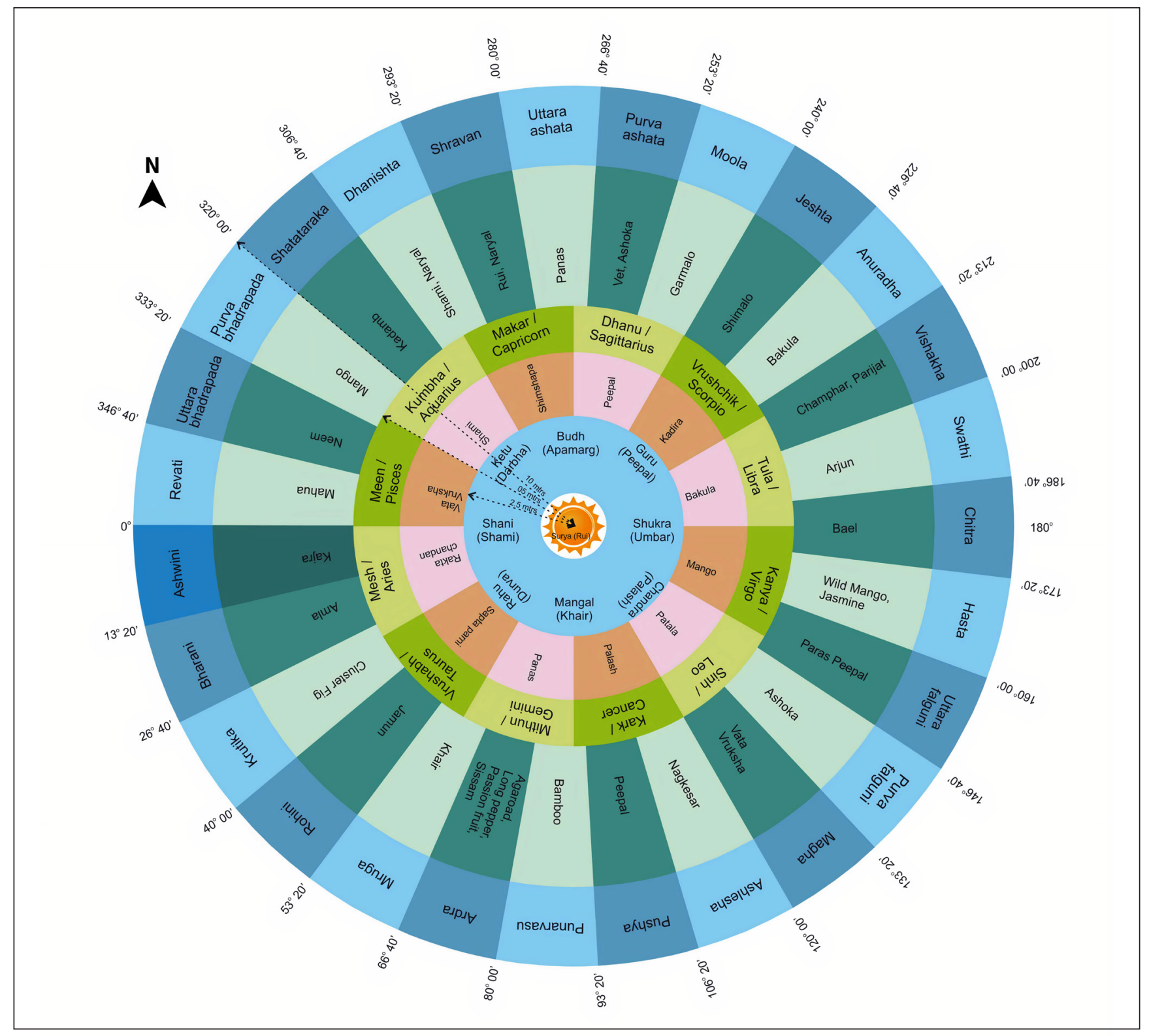

Figure1: Layout of navagraha/rashi/nakshatra vatika of ICAR-CCARI 
Table 1: Details of navagraha vatika plants

\begin{tabular}{|c|c|c|c|c|c|}
\hline SI. No. & Graha (planet) & Position & Plant name & Botanical name & Family \\
\hline 1. & Surya (Sun) & Middle & Rui (Milk weed) & Calotropis gigantea & Euphorbiaceae \\
\hline 2. & Chandra (Moon) & South-East & Palash (Flame of forest) & Butea monosperma & Fabaceae \\
\hline 3. & Budha (Mercury) & North & Apamarg (Prickly chaff flower) & Achyranthus aspera & Amaranthaceae \\
\hline 4. & Shukra (Venus) & East & Umbar (Cluster fig) & Ficus racemosa & Moraceae \\
\hline 5. & Mangal (Mars) & South & Khair (Cutch tree) & Acacia catechu & Fabaceae \\
\hline 6. & Bruhaspati/ Guru (Jupiter) & North-East & Peepal (Sacred fig) & Ficus religiosa & Moraceae \\
\hline 7. & Shani (Saturn) & West & Shami (Spunge tree) & Prosopis cineraria & Mimosaceae \\
\hline 8. & Rahu (Dragon's head) & South-West & Durva (Bermuda grass) & Cynadon dactylon & Poaceae \\
\hline 9. & Ketu (Dragon's tail) & North-West & Darbha (Halfa grass) & $\begin{array}{l}\text { Desmostachya } \\
\text { bipinnata }\end{array}$ & Poaceae \\
\hline
\end{tabular}

\section{Importance of Navagraha vatika Plants}

\subsection{Surya: Rui (Milk weed)}

Surya governs head, stomach, skin, bones and right eye in our body. The plant associated with Surya is Rui (Madar), a wasteland weed. This is a common shrub found everywhere in tropical India. Its flowers and leaves are used to worship in temples. The parts used for medicinal purpose are leaves, flowers, dried roots and root bark. The latex of this plant has very high medicinal values. It possesses hypertensive, antimicrobial (Bhaskar, 2000), anti-diarrheal, antipyretic, antimalarial (Sharma et al., 2000), anti-inflammatory and analgesic properties (Kumar et al., 2000). Dried leaves of madar have aphrodisiac and purgative properties and tender leaves are used to treat migraine (Meena et al., 2011). Warm Leaves are to legs to cure rheumatism (Sebastian and Bhandari, 1984). The mixture of latex and turmeric can help to get rid of skin blemishes and boils. Ear drops prepared by heating ghee in fresh leaves can cure ear infection. Flowers are used to treat cough, asthma, indigestion and cholera. Dried latex and dried roots are used as antidote for snake bite and as abortifacient. Topical application of latex can cure skin diseases and heal wounds.

\subsection{Chandra: Palash (Flame of forest)}

Chandra rules heart, blood, brain, breast and lungs. Palash is associated with this graha. Flowers, leaves, stem bark, roots and gum of palash are traditionally traditionally used as medicines (Mazumder et al., 2011). Flowers of this sacred tree are offered in place of blood in sacrifice rituals. Dry stem is used to create sacred fire during poojas. Palash flowers are used as a brain stimulant and used in treating enlarged spleen and menstrual disorders. It possesses anti-leprotic, antimicrobial, antiulcer, anti-asthmatic and blood purifying properties (Das et al., 2011). Palash also has anti diarrheal, anti stress, anti diabetic anti-diabetic, wound healing and hormone balancing properties. The roots are used to treat snake bites and causes partial sterility in women. Water of soaked flowers is used to bathe to treat skin disorders. Sore throat can be treated using mouthwash prepared by boiling leaves in water. Intake of resin powder with milk can give relief to joint pain. Bad breath can be treated by brushing with Palash twigs.

\subsection{Budha: Apamarg (Prickly chaff flower)}

Budha favours face, hair, nose, chest and tongue. Apamarg is a common weed found in the waste lands. It is having many medicinal values. Its leaf juice is used as ear drop to cure infection. Root juice mixed with rose water is applied to eyes to cure redness. Chewing fresh leaves can cure mouth ulcer. Inhaling ripe seed powder can reduce migraine. It is effective in cold, cough, fever and poisonous bites (Jain and Singh, 2010). Fresh leaf juice can cure dysentery. This plant has spermicidal, activities, anti-allergic properties, cardiovascular protective nature, nephroprotective properties, antiparasitic, antiinflammatory, hypoglyceamic, analgesic and hepatoprotective potency. It has antiperiodic, antimicrobial, Gastric disorders (Pandey et al., 2013). Purgative, antipyretic and are used in various types of gastric disorders.

\subsection{Shukra: Umbar (Cluster fig)}

Physical appearance facial expressions, urinary glands and reproductive organs are governed by Shukra. Umbar is an evergreen tree found in tropical India. Its leaves, fruits, bark, latex and root sap has medicinal value (Trivedi et al., 1969). It has hypoglycaemic, radio protective, chemo-preventive, antiinflammatory, analgesic, antifilarial, antitussive anti-diarrheal, hyptotensive and wound healing properties. It has been extensively used in treatment of biliary disorders, jaundice, dysentery, diabetes, diarrhoea and inflammatory conditions (Ahmed and Urooj, 2010). Tender leaf juice consumption can reduce dysentery. Cotton soaked in leaf latex can be applied on affected areas in fistula and piles. External application of stem latex can cure cracked heels. Water boiled with tree bark can be used as mouth wash in case of oral infection and mouth ulcers. Bark paste is used to treat swellings and boils. Dried fruits are consumed with sugar or honey in case of excessive menstrual bleeding. 


\subsection{Mangal: Khair (Cutch tree)}

Mangal governs marrow, neck and anal region. Khair is a deciduous tree grown in dry regions as a fire break. The gum of this tree is used to adulterant. Black dye extracted from leaves and reddish-brown dye from stem is used as natural colouring agents. The heartwood is used in furniture making. It is used to treat painful throat and cough, skin irritations, asthma, bronchitis, colic diarrhea, dysentery and boils (Sunil et al., 2019). It has astringent property and is used for proper digestion. Kattha used in paan, is prepared by boiling and processing the heartwood of khair tree. Kattha cures mouth ulcers, boils and skin eruption when applied on the affected area. Bark decoction of khair mixed with milk relieves cold and cough. The mixture of khair powder and cinnamon powder helps to cure diarrhea.

\subsection{Bruhaspati/Guru: Peepal (Sacred fig)}

Guru is related to thighs, liver, kidney and pancreas. Peepal tree is associated with this graha. Peepal has great mythological, religious and medicinal importance. It has anticonvulsant, anti diabetic and anti inflammatory properties (Singh et al., 2011). It has also showed wound healing antibacterial properties. It is beneficial in treatment of respiratory and gastric disorders. Ground young root tip with milk is remedy for ameobiasis and dysentery. Bark decoction is remedy for whopping cough and asthma. Intake of powdered tender leaves with milk is administered for abdominal pain. Bark decoction or bark juice used as mouthwash can strengthen gums and reduce tooth ache. Fresh twigs of peepal tree can be used as toothbrush. Topical application of tender root paste can cure skin disease. Latex is applied topically to get rid of ringworms. The laxative nature of fruits helps to get relief from constipation.

\subsection{Shani: Shami (Spunge tree)}

Teeth, muscles, legs and knee are governed by Shani. Shami is the associated tree of Shani graha. It is an evergreen tree with conical spines found in dry arid regions of India. Shami is a medium sized leguminous multipurpose tree with various medicinal uses (Pareek et al., 2015). The stem bark is used to treat rheumatism, common cold and piles. The flowers are used on skin diseases as a blood purifier and as a coolant. Apart from its medicinal benefits; this tree is a part of rituals in Hindu religion and is an excellent source of fuel and timber. Bark decoction is useful in sore throat, mouth ulcer and tooth ache. Tender leaves infusion can cure diarrhoea and dysentery very fast. Seeds have antidiabetic principles and pod is used to cure urio- geneital issues. Leaves also possess insecticidal properties.

\subsection{Rahu: Durva (Bermuda grass)}

Rahu is the shadow body associated with the ascending (or north) lunar node. It is associated with lungs, breathing, neck and legs. Durva is the representative plant of rahu. It is a common weed found all over the country. This medicinal grass is cardio protective, hepato protective and anti-depressant. It is rich in antioxidants. It is a well-known antidiabetic agent.
Heavy bleeding and other menstrual problems are also treated by this grass. It is used as an appetizer, antipyretic agent and used in treating fever, cough and cold. It can be used in as an antiinflammatory, antiemetic, antidiabetic, diuretic and bloodpurifying agent (Rai et al., 2010)

\subsection{Ketu: Darbha (Halfa grass)}

Ketu is the shadow body associated with the descending (or south) lunar node. Ketu governs feet, belly and claws. Darbha grass is the plant assigned for ketu graha. Darbha is a strong tonic. It has astringent, antipyretic and antiviral activities. The antioxidant content of darbha grass is high. It has antihypertensive activity, insecticidal properties and used in various systems of treatment (Murthy and Mahajan, 2016).

Rashi is the sign similar to zodiac in western system. There are 12 rashis like 12 months of a year. According to vedic astrology, people born under a particular rashi will be having some common features related to the respective rashi. The plant species associated with the rashi are high in antioxidants and release more oxygen.

Rashi vatika plants provide good physical and mental health (Mishra, 2018). The details of the rashi vatika plants are given in Table 2.

\section{Importance of Rashi Vatika Plants}

\subsection{Mesh: Raktachandan (Red sandalwood)}

Mesh meaning 'goat' and the rashi is portrayed by the face and horns of a goat. It signifies leadership and strength. Raktachandan is a medium sized tree commonly found in tropical countries. It is commonly used to cure skin problems. It can cure head ache and ensure sound sleep. Raktachandan has antioxidative, antidiabetic, antimicrobial, anticancer, antiinflammatory and hepatoprotective nature (Bulle et al., 2016).

\subsection{Vrishabh: Sapta parni (Devil's tree)}

The vrishabh rashi is depicted by the face and horns of a bull. It shows power and aggressiveness. The tree associated with this rashi is devil's tree. It is an evergreen tree with fragrant flowers. Its leaves and bark have medicinal properties. It has anti-diabetic, anti-inflammatory, anti-spasmodic, antidepressant anti-anxiety and hepato-protective properties (Pankti et al., 2012). The tonic made from this tree is used as a febrifuge, anti-choleric and astringent. It is used to treat fever, malaria, and troubles in digestion, tumours, ulcers and asthma. Leaf juice is applied as eardrop to relieve ear ache. It can cure bowel complaints, catarrhal dyspepsia, diarrhoea, dysentery and skin disorders.

\subsection{Mithun: Panas (Jack fruit)}

Mithun rashi is symbolised by a pair of a boy and a girl. The people born in this rashi are talkative and have dual nature. Jack fruit tree is known as poor man's food. The fruit and seeds are used for human consumption or animal feed, the bark is used as timber or firewood and leaves are used to 


\begin{tabular}{|c|c|c|c|c|c|}
\hline SI. No. & Rashi (Zodiac) & Position & Plant name & Botanical name & Family \\
\hline 1. & Mesh (Aries) & $0-30^{\circ}$ & Rakta chandan (Red sandalwood) & Pterocarpous santalinus & Fabaceae \\
\hline 2. & Vrishabh (Taurus) & $30-60^{\circ}$ & Sapta parni (Devil's tree) & Alstonia scholaris & Apocyanaceae \\
\hline 3. & Mithun (Gemini) & $60-90^{\circ}$ & Panas (Jack fruit) & Artocarpus hererophyllus & Moraceae \\
\hline 4. & Karka (Cancer) & $90-120^{\circ}$ & Palash (Flame of forest) & Butea monosperma & Fabaceae \\
\hline 5. & Singh (Leo) & $120-150^{\circ}$ & Patala (Padri tree) & Stereospermum suaveolens & Bignonaceae \\
\hline 6. & Kanya (Virgo) & $150-180^{\circ}$ & Aam (Mango) & Mangifera indica & Anacardiaceae \\
\hline 7. & Tula (Libra) & $180-210^{\circ}$ & Bakul (Bullet wood) & Mimusops elengi & Sapotaceae \\
\hline 8. & Vrishchik (Scorpio) & $210-240^{\circ}$ & Khair (Cutch tree) & Acacia catechu & Fabaceae \\
\hline 9. & Dhanu (Saggittarius) & $240-270^{\circ}$ & Aswatha/ Peepal (Sacred fig) & Ficus religiosa & Moraceae \\
\hline 10. & Makar (Capricon) & $270-300^{\circ}$ & Sissam (Indian rose wood) & Dalbergia sissoo & Fabaceae \\
\hline 11. & Kumbh (Aquarius) & $300-330^{\circ}$ & Shami (Spunge tree) & Prosopis cineraria & Mimosaceae \\
\hline 12. & Meen (Pisces) & $330-360^{\circ}$ & Vata vruksha (Banyan tree) & Ficus benghalensis & Moraceae \\
\hline
\end{tabular}

make eco-friendly plates or bowls (Samaddar et al., 1985). It also possesses medicinal properties such as anti-bacterial, anti-fungal, anti-malarial, anti-cancerous, antihypertensive activities (Vazhacharickal et al., 2015). The root is used to treat asthma and fever. Leaves have abortifacient and wound healing property. The ash of burnt bark treats ear problems.

\subsection{Karka: Palash (Flame of forest)}

Karka rashi represents the claws of a crab. The people born under this rashi are creative and emotional. The significance of the associated tree, palash is mentioned in session 2.2.

\subsection{Singh: Patala (Padri tree)}

The singh rashi is symbolized by the head and mane of a lion. The people born under this rashi will be dominating and brave. Patala tree is associated with this rashi. It is a large tree with brown bark and pinnate leaflets and fragrant yellow flowers. It is having cardioprotective nature. It is having antibacterial, blood purifying and diuretic properties. The plant extracts of this plant has anti-inflammatory, anticancer, hepatoprotective, antihyperglycemic, antioxidant activities (Balasubramanian et al., 2010) The alternate tree for this rashi is Ber (Ziziphus mauritiana, family: Rhamnaceae).

\subsection{Kanya: Aam (Mango tree)}

Kanya means a maiden girl. It denotes people with organised behaviour. Mango is associated with Kanya rashi. Mango tree is one of the most important fruit in the world. In India, mango fruit is considered as king of fruits. Mango is rich in fiber and vitamins. All parts of the tree have medicinal value (Kalita, 2014). It acts as antioxidant, wound healer, laxative and diuretic. It is anti-diabetic, antiseptic and antdegenerative in nature. The stem bark possesses anti-allergic and antihelminthic property.

\subsection{Tula: Bakul (Bullet wood)}

Tula represents a balance and the people belonging to this rashi will be impartial and maintain harmony. Bakul is a medium sized evergreen tree. It is considered to be sacred and is symbol of love and beauty. The leaves, flowers, fruits, bark and gum are used in medicine to treat various human ailments. It shows antibacterial, antipyretic, analgesic, antiurolithatic, antihelminthic and wound healing properties (Bharat et al., 2012). Dried flower powder can be used as brain tonic. The bark decoction can be used to cure bleeding gum, tooth decay, inflammatory mouth. The fruit pulp Improves fertility in women and ease delivery.

\subsection{Vrishchik: Khair (Cutch tree)}

Vrishchik denotes the stringer of a scorpion. People belonging to this rashi are judicious and revengeful. The features of the associated tree, khair are mentioned in session 2.5.

\subsection{Dhanu: Aswatha/ Peepal (Sacred fig)}

Dhanu represents a dhanus or bow. It has outspoken and honest people. The features of the associated tree, peepal are mentioned in session 2.6.

\subsection{Makar: Sissam (Indian rosewood)}

Makar has crocodile as a symbol. The people born under this rashi will be ambitious and hardworking. In ayurveda, sissam is prescribes as a treatment/ remedy for gonorrhoea and skin ailments. The woody bark is known to possess aphrodisiac, anthelminthic activity, antipyretic and analgesic properties (Sha et al., 2010). It is also used in boils and leprosy. Chewing leaves twice a day for two weeks can cure piles. Leaf paste is applied topically on abscesses. Mixture of honey and leaf juice can be used as eye drop for eye pain. Topical application of sissam oil can cure skin diseases.

\subsection{Kumbh: Shami (Spunge tree)}

Kumbh symbolises a pot filled with water. The people of kumbh rashi will be attractive in nature. The features of shami tree are mentioned in session 2.7. 


\subsection{Meen: Vata vruksha (Banyan tree)}

Meen rashi has a representation by fish. The people born under this rashi are shy and versatile. Banyan tree is commonly known as Burgad or Vata vruksha. Banyan tree symbolises long life span, strength and prosperity. It is a huge evergreen tree with green leaves and aerial roots. It is used to treat dysentery, diarrhoea, leucorrhoea, menorrhagia and nervous disorders (Patel and Gautam, 2014). Bark and milky juice Bark and latex has ant diabetic activity. Seeds are used as coolant and tonic. Rashes are treated by applying the leaf paste.Eye ointment prepared by camphor and Banyan tree used to treating corneal opacity. Joint pains or lumbago can be treated by massaging the affected area externally by latex. Aerial root paste can be used for topical application on pimples. Drinking of bark Bark decoction can reduce can reduce excessive urination.
Nakshatra vatika is a more familiar concept and followed in many places. The plants assigned to each nakshatra may vary in different places based on the climatic situations of that region. There for more than one plant are referred for same nakshatra in different scripts. The details of the nakshatra vatika plants are described in the Table 3.

\section{Importance of Nakshatra Vatika Plants}

\subsection{Ashwini: Kajra (Poison nut)}

This nakshatra is governed by divine twin physician, Aswini kumaras heading light and consciousness. It resembles head of a horse. Ashwini nakshatra can provide a strong nervous system. The tree associated with this nakshatra is 'poison nut'. Seeds and stem bark of this tree possess high medicinal value due to the presence of the alkaloid 'strychnos'. It is

\begin{tabular}{|c|c|c|c|c|c|}
\hline $\begin{array}{l}\text { SI. } \\
\text { No. }\end{array}$ & Nakshatra & Position & Plant name & Botanical name & Family \\
\hline 1. & Ashwini (Beta Arietis) & $0-13^{\circ} 20^{\prime}$ & Kajra (Poison nut) & Strychnos nux-vomica & Loganiaceae \\
\hline 2. & Bharani (41 Arietus) & $13^{\circ} 20^{\prime}-26^{\circ} 40^{\prime}$ & Amla (Indian gooseberry) & Emblica officinalis & Euphorbiaceae \\
\hline 3. & $\begin{array}{l}\text { Kritika (Etatauri } \\
\text { Alcyone-2) }\end{array}$ & $26^{\circ} 40^{\prime}-40^{\circ} 00^{\prime}$ & Umbar (Cluster fig) & Ficus racemosa & Moraceae \\
\hline 4. & Rohini (Aldebaran) & $40^{\circ} 00^{\prime}-53^{\circ} 20^{\prime}$ & Jamun (Java plum) & Syzigium cumini & Myrtaceae \\
\hline 5. & $\begin{array}{l}\text { Mrigashirsha } \\
\text { (Lambda orionis) }\end{array}$ & $53^{\circ} 20^{\prime}-66^{\circ} 40^{\prime}$ & Khair (Cutch tree) & Acacia catechu & Leguminoseae \\
\hline \multirow[t]{4}{*}{6.} & \multirow[t]{4}{*}{ Aardra (Gamma) } & \multirow[t]{4}{*}{$66^{\circ} 40^{\prime}-80^{\circ} 00^{\prime}$} & Sissam (Indian rosewood) & Dalbergia sissoo & Fabaceae \\
\hline & & & Krishna guru (Agar wood) & Aquilaria agallocha & Thymelaeaceae \\
\hline & & & Krishna kamal (Passion fruit) & Passiflora edulis & Passifloraceae \\
\hline & & & Thippali (Long pepper) & Piper longum & Piperaceae \\
\hline \multirow[t]{3}{*}{7.} & \multirow{3}{*}{$\begin{array}{l}\text { Punarvasu (Beta } \\
\text { Geminorium pollux) }\end{array}$} & \multirow[t]{3}{*}{$80^{\circ} 00^{\prime}-93^{\circ} 20^{\prime}$} & Bamboo & Dendrocalamus strictus & Poaceae \\
\hline & & & Bamboo & Bambusa arundinaceae & Poaceae \\
\hline & & & Babul (Gum arabic tree) & Vachellia nilotica & Fabaceae \\
\hline 8. & Pushya (Delta Cancri) & $93^{\circ} 20^{\prime}-106^{\circ} 40^{\prime}$ & Peepal (Sacred fig) & Ficus religiosa & Moraceae \\
\hline 9. & $\begin{array}{l}\text { Ashlesha (Zeta } \\
\text { Hydare) }\end{array}$ & $106^{\circ} 40^{\prime}-120^{\circ} 00^{\prime}$ & $\begin{array}{l}\text { Nagkesar (Indian rose } \\
\text { chestnut) }\end{array}$ & Messua ferrea & Calophyllaceae \\
\hline 10. & $\begin{array}{l}\text { Magha (Regulus/ } \\
\text { Roleonis) }\end{array}$ & $120^{\circ} 00^{\prime}-133^{\circ} 20^{\prime}$ & Vata vruksh (Banyan tree) & Ficus bengalensis & Moraceae \\
\hline \multirow[t]{2}{*}{11.} & $\begin{array}{l}\text { Purva phalguni (Delta } \\
\text { Leonis) }\end{array}$ & $133^{\circ} 20^{\prime}-146^{\circ} 40^{\prime}$ & Palash (Flame of forest) & Butea monospema & Fabaceae \\
\hline & & & Sita Ashok (Ashoka tree) & Saraca asoka & Caesalpinaceae \\
\hline \multirow[t]{4}{*}{12.} & $\begin{array}{l}\text { Uttara phalguni } \\
\text { (Denebala) }\end{array}$ & $146^{\circ} 40^{\prime}-160^{\circ} 00^{\prime}$ & $\begin{array}{l}\text { Payar Peepal (Golden } \\
\text { rumph's fig) }\end{array}$ & Ficus rumphii & Moraceae \\
\hline & & & Paras Peepal (Portia tree) & Thespesia populnea & Malvaceae \\
\hline & & & Pakur (White fig) & Ficus infectoria & Moraceae \\
\hline & & & Shami (Spunge tree) & Prosopis cineraria & Leguminosae \\
\hline
\end{tabular}




\begin{tabular}{|c|c|c|c|c|c|}
\hline $\begin{array}{l}\text { Sl. } \\
\text { No. }\end{array}$ & Nakshatra & Position & Plant name & Botanical name & Family \\
\hline \multirow[t]{2}{*}{13.} & \multirow[t]{2}{*}{$\begin{array}{l}\text { Hasta } \\
\text { (Delta Corvi) }\end{array}$} & \multirow[t]{2}{*}{$160^{\circ} 00^{\prime}-173^{\circ} 20^{\prime}$} & Chameli (Jasmine) & $\begin{array}{l}\text { Jasminum } \\
\text { grandiflorum }\end{array}$ & Oleaceae \\
\hline & & & Ambada (Wild mango) & Spondia magifera & Anacardiaceae \\
\hline 14. & Chitra (Virginis spica) & $173^{\circ} 20^{\prime}-186^{\circ} 40^{\prime}$ & Bael (Stone apple tree) & Aegle marmelos & Rutaceae \\
\hline 15. & $\begin{array}{l}\text { Swati (Alpha Bootis/ } \\
\text { Arcturus) }\end{array}$ & $186^{\circ} 40^{\prime}-200^{\circ} 00^{\prime}$ & Arjun (Arjun tree) & Terminalia arjuna & Combretaceae \\
\hline \multirow[t]{5}{*}{16.} & \multirow{5}{*}{$\begin{array}{l}\text { Vishakha (Alpha } \\
\text { Librae) }\end{array}$} & \multirow[t]{5}{*}{$200^{\circ} 00^{\prime}-213^{\circ} 00^{\prime}$} & Viklo (Red spike thorn) & Mytenus emarginata & Celastraceae \\
\hline & & & Parijat (Night Jasmine) & $\begin{array}{l}\text { Nyctanthes arbour- } \\
\text { tristis }\end{array}$ & Salicaceae \\
\hline & & & $\begin{array}{l}\text { Nagkesar (Indian Rose } \\
\text { Chestnut) }\end{array}$ & Messua ferrea & Calophyllaceae \\
\hline & & & Champhar (Governor's plum) & Flacourtia montana & Oleaceae \\
\hline & & & Dadhiphal (Elephant apple ) & Limonium acidissimum & Rutaceae \\
\hline \multirow[t]{2}{*}{17.} & \multirow{2}{*}{$\begin{array}{l}\text { Anuradha } \\
\text { (Delta Scorpii) }\end{array}$} & \multirow[t]{2}{*}{$213^{\circ} 00^{\prime}-226^{\circ} 40^{\prime}$} & Bakul (Bullet wood) & Mimusops elengi & Sapotaceae \\
\hline & & & $\begin{array}{l}\text { Nagkesar (Indian rose } \\
\text { Chestnut) }\end{array}$ & Messua ferrea & Calophyllaceae \\
\hline \multirow[t]{3}{*}{18.} & \multirow[t]{3}{*}{ Jyeshta (Antares) } & \multirow[t]{3}{*}{$226^{\circ} 40^{\prime}-240^{\circ} 00^{\prime}$} & Shimalo (Red silk cotton tree) & Bombax malabaricum & Bombacaceae \\
\hline & & & Kate savar (Red cotton tree) & Bombax ceiba & Bombacaceae \\
\hline & & & Neem (Margosa tree) & Azadirachta indica & Meliaceae \\
\hline \multirow[t]{3}{*}{19.} & \multirow[t]{3}{*}{$\begin{array}{l}\text { Moola (Lambada } \\
\text { Scorpi) }\end{array}$} & \multirow[t]{3}{*}{$240^{\circ} 00^{\prime}-253^{\circ} 20^{\prime}$} & $\begin{array}{l}\text { Garmalo (Indian laburnum } \\
\text { tree) }\end{array}$ & Cassia fistula & Leguminacae \\
\hline & & & Raal (White damar) & Vateria indica & Dipterocarpaceae \\
\hline & & & Bael (Stoneapple tree) & Aegle marmelos & Rutaceae \\
\hline \multirow[t]{2}{*}{20.} & \multirow{2}{*}{$\begin{array}{l}\text { Purva ashata } \\
\text { (Delta sagittarii) }\end{array}$} & \multirow[t]{2}{*}{$253^{\circ} 20^{\prime}-266^{\circ} 40^{\prime}$} & Vet (Rattan cane) & Calamus rotang & Arecaceae \\
\hline & & & Sita ashok (Ashoka tree) & Saraca indica & Caesalpinaceae \\
\hline 21. & $\begin{array}{l}\text { Uttara ashata } \\
\text { (Sigma sagittavivi) }\end{array}$ & $266^{\circ} 40^{\prime}-280^{\circ} 00^{\prime}$ & Panas (Jack fruit tree) & $\begin{array}{l}\text { Artocarpus } \\
\text { heterophyllus }\end{array}$ & Moraceae \\
\hline \multirow[t]{3}{*}{22.} & \multirow[t]{3}{*}{$\begin{array}{l}\text { Shravan (Alpho } \\
\text { Aquila/ Altair) }\end{array}$} & \multirow[t]{3}{*}{$280^{\circ} 00^{\prime}-293^{\circ} 20^{\prime}$} & Rui (Milk weed) & $\begin{array}{l}\text { Calotropis procera/ } \\
\text { gigantea }\end{array}$ & Asclepiadaceae \\
\hline & & & Nariyal (Coconut tree) & Cocos nucifera & Arecaceae \\
\hline & & & Sita ashok (Ashoka tree) & Saraca ashoka & Caesalpinaceae \\
\hline \multirow[t]{2}{*}{23.} & \multirow{2}{*}{$\begin{array}{l}\text { Dhanishtha } \\
\text { (Beta Dalphini) }\end{array}$} & \multirow[t]{2}{*}{$293^{\circ} 20^{\prime}-306^{\circ} 40^{\prime}$} & Shami (Spunge tree) & Prosopis cineraria & Mimosaceae \\
\hline & & & Nariyal (Coconut tree) & Cocos nucifera & Arecaceae \\
\hline 24. & $\begin{array}{l}\text { Shatataaraka } \\
\text { (Lambda Aquarii) }\end{array}$ & $306^{\circ} 40^{\prime}-320^{\circ} 00^{\prime}$ & Kadamb (Burflower tree) & $\begin{array}{l}\text { Mitragyana parvifolia } \\
\text { (Anthocephalus } \\
\text { kadamba) }\end{array}$ & Rubiaceae \\
\hline \multirow[t]{2}{*}{25.} & \multirow{2}{*}{$\begin{array}{l}\text { Purva Bhadrapada } \\
\text { (Beta pegasi/ } \\
\text { Markab) }\end{array}$} & \multirow[t]{2}{*}{$320^{\circ} 00^{\prime}-333^{\circ} 20^{\prime}$} & Aam (Mango tree) & Mangifera indica & Anacardiacea \\
\hline & & & Neem (Margosa tree) & Azadirachta indica & Meliaceae \\
\hline \multirow[t]{2}{*}{26.} & \multirow{2}{*}{$\begin{array}{l}\text { Uttara Bhadrapada } \\
\text { (Gamma Pegasi/ } \\
\text { Algenib) }\end{array}$} & \multirow[t]{2}{*}{$333^{\circ} 20^{\prime}-346^{\circ} 40^{\prime}$} & Aam (Mango tree) & Mangifera indica & Anacardiacea \\
\hline & & & Neem (Margosa tree) & Azadirachta indica & Meliaceae \\
\hline 27. & Revati (Zeta piscium) & $346^{\circ} 40^{\prime}-360^{\circ} 00^{\prime}$ & Mahua (Indian butter tree) & Madhuca indica & Sapotaceae \\
\hline
\end{tabular}


used to treat stomach disorders, fever, infertility, arthritis, neurological disorders and hydrophobia. Leaves are externally applied as poultice for wound healing (Maji and Pratim, 2017).

\subsection{Bharani: Amla (Indian gooseberry)}

Bharani nakshatrais ruled by planet Venus and presiding deity is Lord Yama, "God of death". It is denoted by triad of faint stars and represent female sexual organ. It primarily relates to the feminine aspect of nature and it has potential to receive, bear, foster and annitulate. The nakshatra plant of Bharani is Amla. It is rich in vitamin C (a potential antioxidant). Amla fruits are used to treat diarrhoea, jaundice and inflammation and it is a potential tonic. Daily consumption of amla in any form will improve health. It also has anti-diabetic and gastroprotective properties. It is very useful in improving eyesight and is best remedy for all kinds of hair problems. Application of decoction of amla powder can cure premature greying and hair fall issues.

\subsection{Kritika: Umbar (Cluster fig)}

Kritika nakshatra is marked by a cluster of seven stars known as Pleadius. The ruling deity is "God of fire". Kritika nakshatra is the source of energy and power. Cluster fig is associated with this nakshatra. The significance of cluster fig is mentioned in the session 2.4 .

\subsection{Rohini: Jamun (Java plum)}

Rohini nakshatra has shape of chariot with five stars in it. It is also called as Cart. Mythology describes Rohini as wife of Moon. The ruling planet is moon and ruling deity is Lord Brahma,'creator of all the creations'. This nakshatra is the expression of supreme growth and true rise. Jamun is a great medicine to treat diabetic mellitus. Regular consumption of dried Jamun seed powder can cure diabetes. It possesses anti-HIV, anti-inflammatory, anti-microbial, anti-fertility, gastro-protective and anti-ulcerogenic properties. Its fruits are processed to make health drinks, preservatives, squash, juices, jellies and wines (Ramteke et al., 2015). Consumption of bark powder mixed with honey, twice a day helps to reduce bleeding diarrhea. The juice extracted from seeds can be used to treat ulcers or sores by applying on the affected area. Fresh juice of tender leaves with black pepper can cure kidney stone and female fertility problems.

\subsection{Mrugashirsha: Khair (Cutch tree)}

Mrugshirsha is a constellation of orion. This nakshatra is ruled by planet Mars and presiding deity is Lord Soma. It is a part of Taurus and Gemini zodiac. It is symbolized by Antelope's head. Mrugashirsha nakshatra is referred to as star of searching. The significance of khair is mentioned in the session 2.5.

\subsection{Aardra: Sissam (Indian rosewood)}

Aardra is associated with the star Betelgeuse. The presiding deity is Rudra. It is symbolized by a tear drop. Ruling planet for this nakshatra is Rahu. Aardra presents intellectual feeling and passionate thinking. The significance of sissam is mentioned in the session 2.10. The alternate plants recommended for
Aardra nakshatra are Agarwood/ Krishna guru (Aquilaria agallocha, family: Thymelaceae); Long pepper/ Thippali (Piper longum, family: Piperaceae; Passion fruit/ Krishna kamal (Passiflora edulis, family: Passifloraceae).

\subsection{Punarvasu: Bamboo}

Punarvasu nakshatra is ruled by planet Jupiter. Aditi is its God of worship. It refers to the brightest star in the constellation of Gemini; Castor and Pollux. Punarvasu means to dwellreside again. It relates to the revival, renewal and restoration. Bamboos are used for soil conservation, industries, ornamental and fuel purposes. It has many medicinal properties that are exploited to epilepsy and feverish diseases (Shukla et al., 2012). Bamboo powder is used in skin care as an exfoliater and cleanser. It is diuretic, sweet, coolant and antibacterial in nature. It is also used in heat strokes. The alternate plants recommended for Punarvasu nakshatra are Bamboo (Bambusa arundinaceae, family: Poaceae) and Gum arabic tree/ Babul (Vachellia nilotica, family: Fabaceae).

\subsection{Pushya: Peepal (Sacred fig)}

Pushya nakshatra is also known as Tishya. It comes under cancer constellation. It is ruled by planetary forces of Saturn and divine force of Jupiter. Its presiding deity is Jiva. Pushya is known to be one of the most lovable nakshatra. The relevance of peepal tree is mentioned in the session 2.6.

\subsection{Aashlesha:Nagkesar (Indian rose chestnut)}

Ashlesha nakshatra is also known as clinging star/hydra. The planetary lord is mercury and presiding deity is Naga. It represents coiled serpent. It is considered to be a sharp nakshatra. Nagkesar (Mesua) tree is an evergreen medium to large sized ornamental tree. Bark, flowers, leaves, root, stamens and seeds of this tree has medicinal properties. It has anti-pyretic, antimicrobial, anti-cancerous, carminative, diuretic and expectorant properties. It is also used as an immunity booster agent, herbal supplement for the treatment of bleeding piles, dysentery, itching, sweating, skin problems and vomiting. The powder of dried flowers if consumed in the dosage of $1 / 4^{\text {th }}$ of tablespoon with hot water can cure bleeding piles. Application of seed oil to the affected joints can treat rheumatism. The heated leaves are applied to chest to treat cold and cough. Consumption of fruits can resolve gastric troubles. Seed extracts have anti-microbial properties (Chanda et al., 2013).

\subsection{Magha: Vata vruksh (Banyan tree)}

According to Indian astrology, Magha is an important nakshatra. It corresponds to the star Regulus. The ruling planet for this nakshatra is Ketu and it spans through the constellations Leo and Virgo. Magha nakshatra is ruled by Pitra. It blesses with leadership qualities. The importance of banyan tree is mentioned session 3.12.

\subsection{Purva phalguni: Palash (Flame of forest)}

Purva Phalguni nakshatra is also known as Bhagadvaita. 
It spins through Leo constellation and is symbolized by swimming hammock. This star symbolizes joy and creation. It is considered to bring good fortune and good luck. Palash is the tree form of Agnidev, 'God of fire'. The features of palash tree are mentioned in the session 2.2. The alternate plant for this nakshatra is Sita ashoka (Saraca asoka, family: Caesalpinaceae).

\subsection{Uttara phalguni: Payar peepal (Golden rumph's fig)}

Uttara Phalguni nakshatra is ruled by planetary force of Sun. It has a shape of legs of bed-stead with two stars. It derives its divine force from its governing deity Aryamam 'God of Favours'. Different parts of the plant are traditionally used as fodder and food. Leave, fruits, bark, latex, and sap of the root are medicinally important in the traditional system of medicine in India. The leaf decoction is used for mouth wash and ulcers. The latex is applied on boils, blisters and measles. This tree has aphrodisiac, anti-diabetic, astringent and stomachic properties. The root sap is topically applied for mumps and is valuable medicine to treat gonorrhoea. Paras peepal (Thespesia populnea, family: Malvaceae); Shami/Khejdi(Prosopis cineraria, family: Leguminosae); Pakur (Ficus infectoria, family: Moraceae) are the alternate plants recommended for this nakshatra.

\subsection{Hastha: Ambada (Wild mango)}

Hastha nakshatra is also known as Corvi. The presiding deity is Sun and the ruling planet is Moon. It is symbolised by closed hand. It is a light or swift constellation. It centres the zodiac of Virgo. It is demarcated by the powerful symbol of fist. It derives its glittering power arena from its deity Sun. Hastha gives the ability to achieve goals in a complete and immediate manner. All parts of wild mango tree are used as medicine against various human diseases. Fruit can be used as an antidote for poisoning. Bark possesses rubifacient property. The decoction made from root bark helps to cure gonorrhoea and regulates the menstrual cycle. The juice extracted from leaves is Eardrop. Jasmine (Jasminum grandiflorum, family: Oleaceae) is the alternate plant for Hastha nakshatra.

\subsection{Chitra: Bael (Stoneapple tree)}

Chitra nakshatra is represented by a single star and is also known as star of opportunity. The ruling deity is Twashtra (Cosmic craftsmen of universe) and ruling planet is Mars. This is nakshatra of prosperity. Chitra stands for big, bright shining jewel. It comes under zodiac Virgo and Libra. Bael tree has spiritual and religious importance in India. The fruit possesses broad range of therapeutic effects that includes antioxidant, antibacterial, antiviral, anti-diarrheal, gastroprotective, anti-ulcerative colitis, anti-diabetic and cardioprotective properties. The leaves are used as abortificent and contraceptive in women (Choudhary et al., 2017). Bael is also used to treat jaundice, diarrhoea, small pox and asthma. The decoction of root and bark is used in the treatment of fever. Bael fruits are used as dietary supplements in form of murabba, pudding and jellies. This is also useful for treating peptic ulcers, dysentery and respiratory diseases. Bael leaf juice with black pepper powder is used to treat jaundice. Bael fruit can be consumed directly to stop dysentery. Typhoid is cured by using paste of leaves and honey. Daily consumption of bael fruit regularly for three months; removes body toxins and cures chronic constipation. Chewing of leaves on empty stomach helps to control diabetes.

\subsection{Swati: Arjun (Arjun tree)}

Swati nakshatra is known as self going star. This nakshatra comes in Libra zodiac. The ruling planet is Rahu and the ruling deity is Vayu, 'God of wind'. It is symbol of creativity, art and freedom. Arjun tree is an important cardio-protective agent mentioned in ayurveda. The decoction of bark is used as mouths wash for ulcers and is best antacid. The bark ashes are powerful remedy for snake bites and scorpion bites. The fruit paste is applied topically on wound. The leaf juice is used in earache treatment and the bark paste is used for treating heart ailments. The mixture of bark paste and honey is used to improve the skin complexion. Oral intake of bark helps in controlling high blood pressure. Regular consumption of tree bark with milk can cure all kind of heart disease. Leaf juice is used as an eardrop to relive pain.

\subsection{Visakha: Champhar (Governor's plum)}

Vishakha nakshatra is symbolized by four stars in the shape of pylon. It is ruled by planet Jupiter and the deity is Indragni. It symbolizes power, position and authority. It comes under zodiac Libra and Scorpio. The fruits, leaves, bark and roots of chamfer have various uses. Leaves can be used to treat asthma since it act as a sedative. Asthma as a sedative agent. The bark possesses pain killer properties and is used in infantile fever and rheumatic pain. The gum obtained from bark is used to treat cholera. Fruit has astringent and diuretic properties. The root extract of this plant has anti-bacterial properties (Eramma and Gayatri, 2013). The alternate plants recommended for Vishakha nakshatra are Parijat (Nyctanthes arbour-tristis, family: Oleaceae); Elephant apple (Limonium acidissimum, family: Rutaceae); Nagkesar (Messua ferrea, family: Calophyllaceae) and Viklo (Mytenus emarginata, family: Celastraceae).

\subsection{Anuradha: Bakul (Bullet wood)}

Anuradha nakshatra is formed with two stars in the form of umbrella or the lotus flower. The governing planet is Saturn and the ruling deity is Mitra, 'God of friendship'. It symbolizes the ability and determination of blooming in great difficulties. The relevance of bakul tree is mentioned in the session 3.7.

\subsection{Jyeshta: Shimalo (Red silk cotton tree)}

Jyeshtha nakshatra is a big star as the name indicates. Jyeshtha means bigger or older. It is a red nakshatra in the form of an ear ring. It is headed by Lord Indra. This nakshatra is bestowed by the power of accomplishing targets. Shimalo is found everywhere in India. Leaves, flowers, fruits, bark, roots, seeds and gum possess various medicinal properties (Vandana 
and Chaudhary, 2017). It is used to treat STDs, menstrual abnormalities, abortifacient, diuretic and antioxidant, antipyretic and analgesic activity. Consumption of filtered juice of leaves purifies the blood. Leucorrhoea can be cured by taking root powder twice a day. The bark paste is applied to the wound to heal fast. The powder of dried flower is used as tonic for weakness. The alternate plants are Kate savar (Bombax ceiba, family: Bombacaceae); Pine (Pinus sp., family: Pinaceae) and Neem (Azadirachta indica, family: Meliaceae).

\subsection{Moola: Garmalo (Indian laburnum tree)}

Moola nakshatra remains in Sagittarius zodiac. The ruling deity is Goddesses Niti. It gives the power for destruction and ruin. The ruling planet is Jupiter. It blesses with capability to use maximum will power in life. It is symbolized by the group of eleven stars in the shape of the tail of lion. Indian laburnum is also known as Golden shower tree. It is one of the most widespread trees in Indian deciduous forest. It is responsible for various therapeutic potential such as anti-diabetic, larvicidal, anti-cancerous and antibacterial. The fruit pulp is used as mild laxative as well as cardio tonic and stomachic. The leaves are used against fever. The leaves are used for malaria and rheumatism. Its bark is used to treat skin disease (Kumar et al., 2017). The roots are used against syphilis and leprosy while the flower buds are known give relief from constipation. Intake of fruit pulp with sugar once a day relieves constipation. The leaves possesses anti-arthritic property. Leaves (12-24 g) are fried in ghee and consumed two times a day. Decoction of fruit pulp in ghee cures chronic cough. Leaf juice can be used as dressing for the ringworm and it relieves irritation and swelling. It is harmful when consumed during pregnancy. Dhup/Black dammer (Canarium strictum, family: Burseraceae); Raal (Vateria indica, family: Dipterocarpaceae); Bael/ Bilva (Aegle marmelos, family: Rutaceae) are the alternate plants for this nakshatra.

\subsection{Purvashata: Vet (Rattan cane)}

Purvashata nakshatra is also called as Jal nakshatra. It consists of two stars forming a shape of elephant's teeth. The ruling deity of this nakshatra is water and governing planet is Venus. Purvashata means unbeatable. 'Rattan cane' is also called as 'Rattan palm'. The fruit of this plant is edible and yields an astringent resin 'Dragon blood'. This is used as a dye and in painting, to treat respiratory and gastrointestinal disorders. It also possesses wound healing property, anti-bacterial, antidiabetic, anti-inflammatory and anti-ulcer properties

(Jaimik et al., 2011). Wood is a vermifuge, roots are used to treat chronic fever and antidote for snake venom. The alternate plant recommended for this nakshatra is Sita ashoka (Saraca asoka, family: Caesalpinaceae).

\subsection{Uttarashata: Panas (Jack fruit tree)}

Uttarashata nakshatra forms a shape of stage consisting of four stars. It can be seen in the North direction in sky. The ruling planet is Venus and the deity is Vishwadeva. It blesses one with the capability of learning good things. The features of jack fruit tree are mentioned in the session 3.3.

\subsection{Shravan: Rui (Milk weed)}

Shravan nakshatra is also known as Ashwath. It comes under the Capricorn zodiac. The deity of this nakshatra is Vishnu and the ruling planet is Moon. It consists of three stars which are considered to be in the shape of Lord Vishnu's three footsteps. Shravan nakshatra blesses with fame, popularity and ability to listen. The medicinal significance of rui plant is mentioned in the session 2.1.

\subsection{Dhanishta: Shami (Spunge tree)}

Dhanistha nakshatra is alternatively called as Shravishtha, 'Star of symphony'. The ruling planet is Mars, shape is circle and the ruling deity is Asht vasvaas. It depicts the situation of wealth and glory. The relevance of shami tree is mentioned in the session 2.7. The alternate plant recommended is coconut tree (Cocos nucifera, family: Arecaceae).

\subsection{Shatataraka: Kadamba (Burflower tree)}

Shatataraka/ Shatabisha nakshatra means, 'The hundred stars'. It comes under Aquarius zodiac. It is ruled by God Varun 'God of Rains' and governing planet is Rahu. Kadamba treeis an auspicious tree mentioned in Sanskrit literatures. The leaves, root, fruits and bark skin are used for medicinal purpose. The leaves show wound healing property and hence it is externally used to dress the wounds and ulcers (Kumar, 2007). The juice of fresh fruit is used to quench thirst in fevers and improves the milk quality of lactating mother. The bark skin is used to treat skin diseases and is antipyretic and antiinflammatory in nature. The roots are favourable for children in case of fever and stomach ache.

\subsection{Purva Bhadrapada: Aam (Mango)}

Purva Bhadrapada nakshatra is also known as Yamal Sadrish. It consists of two stars which look like twins. The governing planet is Jupiter and deity is Aj Ekpad. Neem (Azadirachta indica, family: Meliaceae) is the alternate plant recommended for Purva Bhadrapada nakshatra.Medicinal uses of mango tree are mentioned in the session 3.6.

\subsection{Uttara Bhadrapada: Neem (Margosa tree)}

Uttara bhadrapada nakshatra consist of two stars in the shape of bed. Its status is in Pisces. The ruling planet in Saturn and deity is Ahirbudhya. It is believed to be one of the luckiest nakshatra as it blesses with salvation and peace. Neem tree has therapeutics implication in diseases cure and formulation based on the fact that neem is also used to treat various diseases (Alzohairy, 2016). The bark and leaf extracts shows anti-inflammatory and wound healing property. The seed possesses antipyretic activity. The root bark and the leaf extract are an important anti-diabetic agent in Ayurveda. Neem has antimicrobial activities and neem based mouth wash is anti-gingivitis and is effective in reducing periodontal indices. Daily intake of leaf juice can act as a blood purifier and helps to treat skin diseases. Application of neem leaf paste to scalp treats dandruff, hair fall and itchy scalp. The mixture 
of neem leaf juice and yoghurt can cure ringworm. Neem leaf tea with black pepper and honey can help to lower the cholesterol, and prevents kidney and liver problems. Burning dried neem leaves will act as mosquito repellent. The alternate plant for this nakshatra is Mango (Mangifera indica, family: Anacardiaceae).

\subsection{Revati: Mahua (Indian butter tree)}

Revati nakshatra is formed by the combination of 32 small nakshatras and forms a shape of 'mridang' in the sky. This nakshatra comes under Pisces zodiac. It is ruled by Mercury planet. Mahua tree is known as Indian butter tree. A medium sized to large deciduous tree with a large rounded crown. The seed of Mahua gives high quality fat commercially known as 'Mahua butter' which is substitute for cocoa butter or ghee and is also used as biodiesel. Mahua tree also has industrial application. It is used in manufacture of laundry soaps and lubricants. It also has insecticidal and pesticide property. Various parts of the plant have anti-inflammatory, hepatoprotective, antimicrobial, anti-oxidant and antipyretic properties (Chatterjee and Pakrashi, 2000). The tree bark can also be used as timber. Mahua flowers are sweet and are used for the fermentation process. This tree is a stimulant, demulcent, emollient and has heating properties also. Bark is used in diabetes, rheumatism, ulcers, bleeding and tonsillitis. In skin diseases, the juice of flowers is applied. The decoction of bark in water if taken internally can cure Rheumatism. Seed oil also can be applied externally on the affected area. Bark decoction also helps in managing diabetes. Ulcers can be treated by applying grinded roots. Dried flower powder along with ghee and honey is considered as tonic.

\section{Establishment and Management of Navagraha/Rashi/ Nakshatra Vatika}

\subsection{Selection of area}

Navagraha/ rashi/ nakshatra gardens can be established in tropical or subtropical climate regions with fertile soil, good water supply and drainage facilities. Area should be free from flooding and water logging. Loamy soils with 5.0-6.0 pH is suitable for growing most of the associated tree species.

\subsection{Layout}

Usually, a circular layout representing sun in the middle is followed to establish these gardens. The direction and angle of each tree should be considered while preparing the layout. Based on the availability of space, the spacing between the plants can be adjusted. While preparing the layout, The size of the tree and canopy growth of each species. It is good to provide walking space between the plants, so that people can walk around or jog in the garden or sit beneath the trees for relaxing.

\subsection{Selection of planting materials}

Most of the associated plants are propagated by seeds. Nursery raised seedlings or vegetative propagated plants can be selected for planting after attaining sufficient growth for transplanting. Healthy plants, free from pest and diseases will establish fast. There are some alternate plants suggested for each nakshatra that can be considered for selection based on availability and suitability of the area.

\subsection{Planting}

Most of the plants associated with these garden are hardy and easy to grow. It is advisable to plant the trees in pits filled with organic manure in May-June to exploit the monsoon. Farm yard manure and other source of manures can be applied to ensure proper nutritional supply. Labelling the trees with botanical information and medicinal significance will be useful to the public.

\subsection{Management and utilization}

The garden should be protected from grazing and harsh sun during initial years. Intermittent weeding, timely irrigation, manuring, canopy management, pest and disease management will help to establish the garden successfully. The trees can be utilized for food and medicinal purpose after proper establishment of the garden.

\section{Conclusion}

The navgraha/rashi/nakshatra vatika are astrologically designed gardens established near sacred places with associated plant species. Earlier such gardens were established to worship and please the deity for good health. All the associated tree species are rich in anti oxidants and phytochemicals. In the present era, such gardens made in parks, public places and schools helps to conserve these plant species ex situ and strengthen the traditional knowledge about the importance of them and also conserve biodiversity.

\section{Acknowledgement}

The authors are deeply thankful to all the Co-Pls of the institute project 'Prospects and promotion of agro ecotourism in coastal regions of India'. We also thank, Dr.A.R. Desai, Head i/c (Hort. Sciences section) for his support, Mr. Viswajit Prajapathi, Technical officer (Computer) for designing the layout of the gardens, Mrs. Aviprit V. Ubarhande, Young Professional -II and Mr. Rupesh Devidas, Young Professional -I for their help in collection of plants, establishment and management of navgraha/rashi/nakshatra vatika at ICAR-CCARI, Goa.

\section{References}

Ahmed, F., Urooj, A., 2010. Traditional uses, medicinal properties and phytopharmacology of Ficus racemosa: A review. Pharmaceutical Biology 48(6), 672-681.

Alzohairy, M.A., 2016. Therapeutics Role of Azadirachta indica (Neem) and their active constituents in diseases prevention and treatment. Evidence-Based Complementary and alternativemedicine.http://dx.doi. org/10.1155/2016/738250, 1-9.

Balasubramanian, T., Chatterjee, T.K., Sarkar, M., Meena, 
S.L., 2010. Antiinflammatory effect of Stereospermum suaveolens ethanol extracts in rats, Pharmaceutical biology 48(3), 318-323.

Bharat, G., Pathak, S., Parabia, M., 2012. Ethnobotanical, phytochemical and pharmacological review of Mimusops elengi Linn. Asian Pacific Journal of Tropical Biomedicine 2(9), 743-748.

Bhaskar, V.H., 2000. Antimicrobial Activity of Calotropis procera Seeds. Asian journal of chemistry 21(7), 5788-5790.

Bulle, S., Reddyvari, H., Nallanchakravarthula, V., Vaddi, D.R., 2016. Therapeutic Potential of Pterocarpus santalinus L.: An Update. Pharmacognosy Reviews 10(19), 43-49. Doi: 10.4103/0973-7847.176575.

Chanda, S., Rakholia, K., Parekh, J., 2013. Indian medicinal herb: Antimicrobial efficiency of Mesua ferrea L. Seed extracted in different solvents against infection causing pathogenic strains. Journal of Acute Diseases. Doi.10.1016/S2221-6189 (13) 60143-2, 277-281.

Chatterjee, A., Pakrashi, S.C., 2000. The Treatise on Indian Medicinal Plant 4, 56-58.

Choudhary, Y., Saxena, A., Kumar, Y., Kumar, S., Pratap, V., 2017. Phytochemistry, Pharmacological and traditional uses of Aegle marmelos. UK Journal of Pharmaceutical and Biosciences 5(5), 27-33.

Das, M.S., Mazumdar, P.M., Das, S., Das, S., 2011. Butea monosperma (LAM.) kuntze- A comprehensive review. International Research Journal of Plant Science 2(7), 1390-1393.

Eramma, N., Gayathri, D. 2013. Antibacterial potential and phytochemical analysis of Flacourtia indica (Burm.f.) Merr. root extract against human pathogens. Indo American Journal of Pharmaceutical Research 3, 3832-3846.

Jaimik, R.D., Nimish, P.L., Patel, R.G., Jivani, N.P., Bhatt, N.M., 2011. Phytopharmacological properties of Bambusa arundinacea as a potential medicinal tree: An Overview. Journal of Applied Pharmaceutical Science 01 (10), 27-31.

Jain S.P., Singh, J., 2010. Traditional medicinal practices among the tribal people of Raigarh (Chatisgarh), India. Indian Journal of Natural products and Resources 1(1), 109-115.

Jain, S.K., Kapoor, S.L., 2007. Divine botany-universal and useful but under exploredtraditions. Indian Journal of Traditional Knowledge 6(3), 534-539.

Kalita, P., 2014. An Overview on Mangifera indica: Importance and Its various pharmacological actions. Pharma Tutor Magazine 2(12), 72-76.

Kumar, A., Satish, S., Sayeed, I., Hedge, K., 2017. Therapeutic uses of Cassia fistula: Review. International Journal of Pharma andChemical Research 3(1), 38-43.

Kumar, V., 2017. Medicinal Properties of Anthocephalus indicus (Kadam): An indigenous medicinal Plant. Era's Journal of Medicinal Research 4(2), 7-11.
Kumar, V.L., Dewan, S, Kumar, S., Singh, H. 2000. Inflammation induced by latex of Calotropis procera: A new model to evaluate anti-inflammatory drugs. Journal of Pharmacological and Toxicological Methods 43, 219-224.

Maji, A.K., Pratim, B., 2017. Strychnos nux-vomica: A Poisonous plant with various aspects of therapeutic significance. Journal of Basic and Clinical Pharmacy 8, S087-S103.

Mazumder, P.M., Das, M.K., Das, S., Das, S., 2011. Butea monosperma: A comprehensive review. International Journal of Pharmaceutical Sciences review and Nanotechnology 4(2), 1390-1393.

Meena, A.K., Yadav, A., Rao, M.M., 2011. Ayurvedic uses and pharmacological activities of Calotropis procera Linn. Asian Journal of Traditional Medicines 6(2), 45-53.

Mishra, S., 2018. Rashi Nakshtra Vatika and Human Health. Journal of Conventional Knowledge and Holistic Health 2(1), 1-3.

Murthy, A.R., Mahajan, B., 2016. Medicinal importance of Darbha- A review. Journal of Ayurvedic and Herbal Medicine 2(3), 89-95.

Pandey, N.K., Sharma, H.P., Amit, P., Jain, P., 2013. A review on potential magic folk herbal medicinal plant: Achyranthes aspera L. International Journal of Medicinal Plants 105, 350-363.

Pankti, K., Payal, G., Manodeep, C., Jagadish, K. 2012. A phytopharmacological review of Alstonia scholaris. A panoramic herbal medicine. International Journal of Research in Ayurveda and Pharmacy 3(3), 367-371.

Pareek, A.K., Garg, S., Kumar, M, Yadav, S.,2015. Prosopis cineraria: A gift of Nature for Pharmacy. International Journal of Pharma Sciences and Research 6(6), 958-964.

Patel, R., Gautam, P., 2014. Medicinal Potency of Ficus bengalensis: A Review. International Journal of Medicinal Chemistry and Analysis 4, 53-58.

Rai, P.K., Jaiswal, D., Rai, D.K, Sharma, B., Watal, G., 2010. Antioxidant potential of oral feeding of Cynodon dactylon extract on diabetes-Induced oxidative stress. Journal of Food Biochemistry 34(1), 78-92.

Ramteke, V., Kurrey, V., Kar, S., 2015. Jamun: A traditional fruit and medicine. Popular Kheti 3(3), 188-190.

Samaddar, H.M., 1985. Jackfruit. In: Bose, T.K., Mitra, S.K. (Eds.), Fruits of India: Tropical and Subtropical. Calcutta, India: Naya Prokash, 638-649.

Sebastian, M.K., Bhandari, M.M., 1984. Medico-ethno botany of mount Abu, Rajasthan, India. Journal of Ethnopharmacology 12(2), 223-230.

Sha, M.H., Mukhtar, I., Khan, S.N., 2010. Medicinal importance and association of pathological constraints with Dalbergia sissoo. Pakistan Journal of Phytopathology 22(2), 135-138.

Shukla, R., Sumit, G., Sajal, S., Dwivedi, P.K., Mishra, A., 2012. A medicinal importance of Bamboo. International Journal of Biopharm and Phytochemical Research 1(1), 9-15. 
Singh, D., Singh, B., Goel, R.K., 2011. Traditional uses, phytochemistry and pharmacology of Ficus religiosa: A review. Journal of Ethnopharmacology 134, 565-583.

Sunil, M.A., Sunitha, V.S., Radhakrishnan, E.K., Jyothis, M. 2019. Immunomodulatory activities of Acacia catechu, a traditional thirst quencher of South India. Journal of Ayurveda and Integrative Medicine 10, 185-191.

Trivedi, C.P., Shinde, S., Sharma, R.C., 1969. Preliminary phytochemical and pharmacological studies on Ficus racemosa extract (Gular). Indian Journal of Medical Research 57, 1070-1074.
Vandana, M., Choudhary, A., 2017. Shalmali (Bombax ceiba): Versatility in its therapeutics. International Journal of Green Pharmacy 11(3), S401-S406.

Vazhacharickal, P.J., Sajeshkumar, N.K., Mathew, J.J., Kuriakose, A.C., Abraham, B., Mathew, R.J., Albin, A.N., Thomson, D , Thomas, R.S., Varghese, N., Jose, S., 2015. International Journal of Innovative Research and Review 3(2), 83-95. 